\title{
Constant 12 and Hahslm 472319 as Universe Creation Code on Tortoise Shell in Covid Economic Era
}

\begin{abstract}
RM Aziz
Universitas Islam Negeri Jakarta, Indonesia, 15412

*Corresponding author. Email: twelve12hl@gmail.com

ABSTRACT

The purpose of this study is to analyze the meaning contained in the morphology of the tortoise carapace and plastron using an Islamic approach in the Covid pandemic situation and the simultaneous economic and social crisis. The objects in this study include tortoises, the sociological impacts of the economy due to Covid and their relationship with the theory of $\mathrm{H}$ and the Al-Qur'an. Meanwhile, the methodology that will be used in this research is reflexivity and similarity in which the method is to investigate the linkages of the factors that have been mentioned. If you look at its origins, the tortoise shell which has this unique shape makes it an interesting animal to study in the field of vertebrate biology. In this study, the authors will focus on tortoise carapace and plastron. The results obtained in this study are if the tortoise carapace which has a scute of 3 and 1.9 can reflect the values contained in the meaning of Islam, this is evidenced in the Hahslm number 472319. In addition, the marginal number itself has a total scute 24 and 1 nuchal, so can get 7 digits in the numbers $2+4+1=7$.
\end{abstract}

Keywords: 12, 472319, Constant, Hahlsm, Shell, Tortoise.

\section{INTRODUCTION}

In its early beginnings, tortoises first lived on earth about 215 million years ago in the Triassic Period and evolved when they entered the middle of the Jurassic period. In 2012, the oldest fossil turtle in the world was found in Poreba near Zawierce by a group of Paleobiology researchers from Poland. After a series of studies, this newly discovered species is Poterochersis Porebensis which is thought to have lived 215 million years ago during the Late Triassic era.

The name turtle was first derived from a Latin word and a local name. In Indonesia, Ambon, to be precise, has a native species of turtle and is called Kuya Batok, which is then called Kuya according to its first name. This Kuya species has the Latin name Coura Amboinensis. The word Coura comes from the name of this species when it was first discovered in Ambon, Indonesia. Meanwhile, the name Amboinensis refers to the location where this animal was first found, namely in Ambon. In its development, the mention of kuya has another term, called Kura-kura, so that it is easier to pronounce. Until now, the term used by most people is Kura-kura or tortoise / turtle. Turtle is the water turtle, turtle that lives in water. Tortoise is the land turtle, a turtle that lives on a land. In this research this amphibia animal called as tortoise but sometimes can be mentioned as turtle. People know this animal with the shell usually called as turtle. It is estimated that there are about 270 types of turtles living at this time with each species having its own characteristics that are different from other reptile animals. Turtles have body sizes ranging from small, with a maximum size of only $9.6 \mathrm{~cm}$, such as the species Homopu Signatus Speckled Padloper in South Africa. Until the largest, whose size reaches 3 meters, such as the Leatherback type (Dermochelys Coriacae).

Referring to the explanation of the research, it can be concluded that turtles are reptiles that have lived on earth for hundreds of years. While the difference between tortoises and sea turtles lies in their fingers, tortoises have nails and webs between their nails and sea turtles have legs that are not flat like tortoises, which then allow the sea turtle to swim properly.

Sea turtle and tortoise organisms are related to other animals such as birds and amphibian species because there is a common ancestral line with birds and crocodiles. This is called a cladogram. The ancestors of the turtle themselves are much older than their human ancestors, the ancestors of the turtle have been around for 215 million years, while the ancestors of humans only appeared 150 thousand years ago. Since appearing 215 
million years ago, turtles have retained the same shell morphology to this day. The anatomy of the tortoise's carapace has a meaning about the concept of life from the beginning of the creation of the universe when viewed from the shape of the scuting. The concept of life in the universe is an extension of the meaning of the dyntivity of the scute.

There are seven types of tortoises living on earth at this time which have habitats on the Pacific peninsula, leatherback and loggerhead tortoises in Indonesia, green tortoises, hawksbill and lekang tortoises. Sea turtles and tortoises basically have differences in their shells because sea turtles themselves have a spine that follows the shape of their shell and is different from plate turtles.

Male turtles have a carapace $40 \%$ longer than their body width, whereas female turtles only have a carapace $10 \%$ longer than their body width. This makes the carapace and head of the male turtle slimmer than that of the female, while the carapace and head of the female tortoise tend to be wider.

Carapace has a very vital role for tortoises. Apart from functioning as protection from predators and rock hits, carapace functions to transmit nutrients to the tortoise and also protects the tortoise's body from high pressure water. In recent years, several studies have revealed that there is a relationship between the structure of the tortoise's carapace and the resulting performance of the tortoise's carapace. In general, the tortoise's carapace has 49 bone plates, of which several bone components consist of horn scales which afterwards consist of nuchal (anterior) scales, 5 supraygal (posterior) scales, 4 pleural scales which become a barrier for vertebral scales and 11 marginal scales. If seen specifically, this can differ from one species to another because tortoises themselves have many species and their variations [1].

In a study examining the carapace of African Spurred tortoises (Centrochelys Sulcata), sulcata tortoises were selected as a representative reference material because the carapace size of these tortoises provided sufficient samples for consistency and repeatability tests. Tortoises of this type are taxonomically included in the range of species of reptiles and include land and desert habitats. With an average body length of $80 \mathrm{~cm}$ and weight when adults can reach $100 \mathrm{~kg}$, sulcata tortoises are included in the third largest tortoise in the world. Thus, if we refer to the protective side of capability, this type of tortoise has a stronger carapace than the type of turtle that lives in water [2].

Carapace and plastron are part of the turtle shell. With this unique shape, carapace and plastron have a number of scutes which, when viewed from the point of view of Theory $\mathrm{H}$, have messages in the form of worship values. In addition, the number of scutes on the carapace and plastron of the turtle also has a connection with the
Ka'bah when referring to the verses of the Al-Qur'an which describe the Ka'bah.

Literally and meaningfully, the theory of $\mathrm{H}$ in its philosophical values requires deepening and an ontological approach so that it can be associated with Islam. In the development of Islamic institutions which Kaffah epistemologically as well as the presence of new terminological elements, can present a comprehensive approach to be able to find out the meaning contained in $\mathrm{H}$ theory. In general, to be able to realize the meaning of the value of worship in life. To be able to know in depth, one must be able to look at the philosophical value side of theory $\mathrm{H}$ by making an analogy gradually in order to find the background to the concept of Islamic values [3].

In accordance with the explanation of the verse in the Al-Qur'an which reads "silmi kaffah", the word silmi is a derivation of the letters sin, lam, mim. Regarding the basic words sin, lam, mim basically has a solution to be able to develop the concept of researching the basic framework and be able to solve problems, because in Islamic studies itself it is necessary to have a methodology to overcome various limitations in order to find a good method in practice.

The formula $\mathrm{H}=\mathrm{A}, \mathrm{h}(\mathrm{S}, \mathrm{L}, \mathrm{M})$ in Theory $\mathrm{H}$ has the meaning of the number 472319. Apart from having a connection with a tortoise shell and its relation to letters in the Al-Qur'an, the basis for the meaning of the number Hahslm is also related to Covid.

The main focus of the world's attention in connection with the Covid pandemic that has spread on a global scale is located in the city of Wuhan, located in Hubei Province, China. The beginning of the epidemiology of this pandemic was when symptoms of respiratory disease caused by the $2019 \mathrm{nCoV}$ corona virus were discovered which were thought to have originated from the Huanan Seafood Wholesale Market, where there was also the sale of live animals. On December 31, 2019, WHO as the world health authority in charge through the Chinese health authority gave an ultimatum to health authorities in Hong Kong, Macau, and Taiwan to immediately increase surveillance at the border. This then caused public panic because the majority of the public considered the situation a new threat to health with the emergency situation at that time [4].

In the beginning, Covid only occurred in the place where the first case of the disease broke out at the end of December 2019, namely in Wuhan, China. Then in the end it was discovered that if Covid can be transmitted between humans, it is happening so fast that it spreads to various countries in just a few months. Including Indonesia is one of the countries infected with the Covid virus.

The outbreak of the Covid virus, which occurred very quickly, made several countries in the world move quickly by imposing lockdown policies in order to 
minimize the spread of this virus. Indonesia itself through its government has begun to impose Large-Scale Social Restrictions (PSBB) which are in Indonesian, namely Pembatasan Sosial Berskala Besar (PSBB) to reduce the number of spread of this Covid virus.

The effects that occurred as a result of this pandemic had an adverse effect on the economic downturn, which was marked by a decline in various sectors, unemployment and weakening demand for goods and services due to declining public incomes. Apart from the impact of the decline in the economic sector, Covid also disturbs the public psychologically due to concerns from this virus.

\subsection{The Origin of The Turtle Skeleton}

Since 260 million years ago turtles have appeared on earth, until modern times like today many scientists are amazed by the shape of the turtle's backbone structure that covers almost all parts of its body. In this world, only turtles have a shell on their back. The question is how a species such as turtles could have evolved a part of the spinal cord that has a unique shape. Things like this will continue to be a big question for many people.

Turtles with their very unique body shape are one of the most interesting mysteries in the development of evolutionary morphology, the discovery of several tortoise body skeletons and the latest development of research studies that focus on tortoise shell parts have provided important information on this subject. The traces of the fossils found provide insight into the stages of tortoise evolution that date back millions of years.

Many biologists argue that molecular data are inherently superior to the morphological information collected in reconstructing phylogenetic relationships. The main problem focuses on the evolutionary divisions between lineages that occur in the past. Because if the problem is the temporal range of the tortoise lineage, then the most likely thing is if this tortoise lineage evolves into a nucleotide at the same location and that only has 4 possibilities in the nucleotide and is related to the substitution.

Current molecular studies of amniote tetrapods take samples of a small set of tetrapod lineages: mammals, tortoises, lepidosaurs, crocodylians, and birds. In the last 100 million years, all these lineage groups have remained diversified and connected to each other by lineages dating from hundreds of millions of years ago.

Many of the researchers wondered about the possibility of identifying the unique skeletal shape of this tortoise on turtle precursors in the fossil record. Over the course of the last few decades along with contemporary studies of the ontogenetic development of the surviving turtle shells in modern times, the researchers described the problem of evolutionary changes that focused on the skeletons of turtles and then re-evaluated the Permian putative stem-turtle [5].

In its development, the tortoise shell that has evolved to date consists of a ventral carapace and plastron which is autapormophic in this part of the skeleton. The turtle shell formation process is accompanied by changes that occur between the spatial relationship of the ribs and the chest girdle. The turtle's own body parts grow sideways into the primordium from the carapacial margin, known as the Carapacial Ridge (CR). This is why the tortoise shell is considered an example of a very evolutionary reform.

\subsection{Spesies of Turtle}

Discussion about tortoise species is something that always attracts the attention of many circles. This is because tortoises have many types of different species. The tortoises that live in this world are divided into 2 types, namely land tortoises and freshwater tortoises / terrapins. Below are the types and kinds of tortoise species, including the following:

\subsubsection{Land Tortoise}

This tortoise species is a type of amphibian. Although they can live in water, this type of tortoise has the main habitat on land and spends most of its life on land. Here are the types of tortoise species:

\subsubsection{Aldabra (Aldabrachelys Gigantea)}

These tortoises are native to Aldabra Island. The aldabra species is the largest tortoise species in the world, the aldabra tortoise has characteristics such as its age can reach 255 years, has a large shell on the neck and is very long, has a body length that can reach 1,1 meters with a maximum weight can reach $100 \mathrm{~kg}$ more. The aldabra tortoise is similar to the giant tortoise from the Seychelles Island.

\subsubsection{Galapos (Chelonoidis Nigra)}

Originally from the Galapagos Islands. Is one of the largest tortoise species in the world. This species can have a body span of up to 1,87 meters, weigh $317 \mathrm{~kg}$ and have a long neck shape like a herbivore. Galapagos tortoises are listed in the Convention on International Trade in Endangered Species of Wild Fauna and Flora as one of the protected species due to their rare existence.

\subsubsection{African Spurred Tortoise (Centrocheys Sulcata)}

The Sulcata Tortoise (African Spurred Tortoise) is native to the Sahara Desert. This species has a Latin name, namely Genus Centrochelys, which has the meaning "succus" or "wrinkles". Sulcata tortoises can 
weigh up to $10 \mathrm{~kg}$ and reach $83 \mathrm{~cm}$ in length. This species has a life span of up to 150 years. In some cases, Sulcata tortoises are widely used as pets.

\subsubsection{Red-footed Tortoise (Chelonoidis Carbonaria)}

Red-footed tortoises have a habitat that is native to South America. The length of this species is only around $40 \mathrm{~cm}$. Having a dark color with carapace like breadcrumbs, this species is also related to the yellowfooted tortoise species. The red-footed tortoise is a protected animal because it is endangered.

\subsubsection{Desert Tortoise (Gopherus Agassizil)}

This species of tortoise has a habitat in the Mojave Desert, United States. Desert Tortoise has a lifespan of 80 years. The size is only about $36 \mathrm{~cm}$ with a maximum weight of $5 \mathrm{~kg}$. This species of tortoise is a protected animal.

\subsubsection{Leopard Tortoise (Stigmochelys Pardalis)}

Has a habitat in the African savanna. The length of this species can reach a range of $70 \mathrm{~cm}$ with a weight of $20 \mathrm{~kg}$ and its age is up to 100 years.

\subsubsection{Gopher Tortoise (Gopherus Polyphemus)}

From the United States of America. Has a length of about $30 \mathrm{~cm}$ with a height of only $37 \mathrm{~cm}$ and a body weight of $6 \mathrm{~kg}$. This species is unique in that it can dig burrows up to 5 meters deep. The Gopher Tortoise reproduces by laying eggs once a year and its existence is protected because it is endangered.

\subsubsection{Radiated Tortoise (Astrochelys Radiata)}

Radiated tortoise or so-called sokake has a native habitat on the island of Madagascar. This species of tortoise is $41 \mathrm{~cm}$ long and weighs $16 \mathrm{~kg}$.

\subsubsection{Elongated Tortoise (Indotestudo Elongata)}

This type of tortoise lives in Southeast Asia. Has a length of about $30 \mathrm{~cm}$ with a weight of only $3.5 \mathrm{~kg}$. This species can be found in Nepal, Bangladesh, India, Burma (Myanmar), Laos, Thailand (Phuket), Kamboja, Vietnam, West Malaysia, South China and Indonesia. Elongated Tortoise is a tropical species.

\subsubsection{Pancake Tortoise (Malacochersus tornieri)}

Tortoise pancakes originate from Tanzania and Kenya. The shape of the flat shell makes this tortoise the name of the pancake. The shape of the shell is flat with a length of $17,8 \mathrm{~cm}$. This species of tortoise is included in the category of protected animals because its existence is threatened with extinction.

\subsubsection{Brazil (Red Ear Slider)}

These tortoises have native habitats in the United States and Brazil. This species of tortoise is a species that is widely used as pets by people in Indonesia.

\subsection{Freshwater Tortoise (Terrapins)}

Water tortoise is a type of tortoise that spends more of its life in water. This can be seen in terms of the tortoise's legs, which look thinner and resemble a paddle. Although these aquatic turtles tend to live in water, they also breathe using their lungs instead of gills. Freshwater turtle habitats are found in rivers, swamps, and ponds. The following are types of freshwater tortoises, including the following:

\subsubsection{Common Snapping Turtle (CST)}

Ferocious tortoise (Chelydra Serpentina), this type of tortoise is about $40 \mathrm{~cm}$ long and can be found in slow and calm rivers as its natural habitat.

\subsubsection{Alligator Snapping Turtle (AST)}

The Alligator Snapping Turtle (Macrochelys Temminckii) is a species of tortoise that has physical characteristics like ancient animals. The lifespan of this type of tortoise can be up to 200 years. The shell shape of this type of tortoise has sharp spines like an alligator, and the sharp jaw shape makes this species have a very strong bite.

\subsubsection{Turtle Spy}

The spy tortoise or which has a scientific name (Chelus Dimbriatus) has a body that can adapt to its natural habitat, namely in fresh water. This type of tortoise is commonly found among the leaves and also plant debris. This species has a triangular head with a rough and hollow body, and a large, flat neck covered with many bumps, warts, skin rims, and also has a hilly back.

\subsubsection{Snake Neck Turtles}

This unique type of tortoise is an animal that can only be found in the wetlands of Rote Island, East Nusa Tenggara. The tortoise, which has the scientific name Chelodina Mccordi, is also called a snake-necked tortoise or long-necked tortoise, so named because its neck and head resemble a snake.

\subsubsection{Pig-nosed Tortoise (Carettocheys Insculpta)}

The pig-nosed tortoise (Carettochelys Insculpta) is a species of freshwater tortoise that can be found in the waters of Papua Indonesia, Papua New Guinea and 
Australia. This type of animal is commonly found in fresh water. These tortoises forage on the bottom of water, riverbanks, lakes and estuaries. Pig nosed tortoises are included in the omnivore category with their diet in the form of plants, fruit and fish.

\subsubsection{Ambon Turtles}

Ambon tortoises are native to Indonesia and originate from Ambon. This tortoise has the scientific name Coura Amobinensis. The physical form of this type of tortoise has a black head with 3 very distinctive yellow stripes. The first part is located around the edge of the head at the top of the eye, then the second is located on the cheeks, and the last is located on the lips.

\subsubsection{Giant Tortoises Cantor's Softshell (Pelochelys Cantorii)}

This tortoise with the scientific name Pelochelys Cantorii is a species that has a natural habitat in fresh water. This type of tortoise belongs to the Trionychidae family. This species is a tortoise native to Southeast Asia which has a length of 1 meter. The uniqueness of the giant tortoise is hunting for food by lying down and not moving at all.

\section{THEORY}

In accordance with the Al-Qur'an Surah Al-Hijr [15]: 87 :

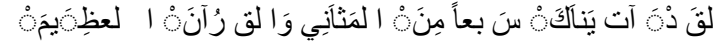

"And We must have given you, [message for Muhammad], seven of the [verses] which are repeated frequently and the great Al-Qur'an" (Al-Hijr [15]: 87).

Referring to from QS. Al-Hijr [15]: 87 can be found the Hahslm formula which has a meaning regarding a special variable, namely 'repeated 7'. This special variable can also be integrated with other variables which have the meaning of 'the noble Al-Qur'an' [6].

In accordance with the explanation according to Roikhan (2015) the meaning contained in verse 15.87, in theory $\mathrm{h}$ results can be obtained from 2 main variables, namely the number 7 (Seven) and Al-Qur'an. The explanation regarding the number 7 (Seven) contains variables with absolute characteristics, while the explanation regarding the Al-Qur'an when factored is then collected into numbers $2,3,1,9$. And also if you use the $2 \times 3 \times 19$ multiplication method, the result will be 114 .

Thus, the explanation in the formula is in the form of five numbers, namely 7,2,3,1,9. These numbers will eventually turn into letters for easy reading as formulas and more efficient use. This formula can be interpreted as the number 7 to A (Alif), 2 to $\mathrm{H}$ (Hanif), 3 to $\mathrm{S}$ (Sin), 1 to $\mathrm{L}$ (Lam) and 9 to $\mathrm{M}$ (Mim). In accordance with this explanation, it can be ascertained that the results obtained are AhSLM. For this reason, in determining the dependent variable in the equation formula, the variable $\mathrm{H}(\mathrm{Ha})$ is needed. If referring to $\mathrm{H}$, then the number 4 will be found.The number 4 is then added up using the independent variable: $2+3+7+1+9=22$. The number 22 can then be used as a digital root, namely $2+2=4$. The final result in this addition is to find the equation of the letter $\mathrm{H}=\mathrm{Ah}(\mathrm{S}, \mathrm{L}, \mathrm{M})$.

In its meaning, this formula has a meaning, for example in theory $\mathrm{H}$ which has the meaning of life, this theory can also be interpreted as A which reflects the relationship with the community, $\mathrm{h}$ which provides an explanation of relationships with fellow humans, $\mathrm{S}$ reflects the relationship with oneself, $\mathrm{L}$ reflects the relationship with the environment, and $\mathrm{M}$ reflects an ethical relationship. The variable $\mathrm{M}$ is what is difficult to find in life [6].

\subsection{Covid}

Covid is a new type of virus (SARS-CoV-2) then known to the public as the corona virus. The virus, which was designated as a pandemic category by WHO on March 11, 2020, was initially identified in the City of Wuhan, China, which eventually spread to various parts of the world. Many of the public think that if the term pandemic is used to indicate the severity of a disease, the fact is that the corona virus is called a pandemic because it measures the extent of the spread of this virus. Prior to the emergence of the pandemic due to the corona virus, there were many other types of influenza viruses that had occurred in the world, for example, the swine flu which emerged in 2009. But in the case of the current pandemic, it was found that Covid was the first pandemic caused by by the corona virus [7].

The problems that occur due to the ongoing pandemic are a new threat to almost all countries in the world. This is inevitable because the threats that occur have an effect on many aspects that affect people's lives. Apart from the sociological effects that occur on society, there are also economic effects (Walmsley, Rose, and Wei 2020). The current pandemic is generally not only about public health problems that are increasingly experiencing a health crisis, apart from these factors this pandemic is the starting point of economic and political crises in countries identified as infected by this virus [8].

In Indonesia, the pandemic that occurs due to the Covid virus is spreading more widely to various regions, this is evidenced by the increasing number of cases and the soaring death rate as a result of Covid. The impact of Covid that is felt in Indonesia has spread to many sectors, namely politics, economy, social, culture, defense and 
security, as well as aspects of welfare that occur in society [9].

In order to minimize the impact that occurs due to Covid, the government as the authorized party has launched and established policies and regulations. The first regulation is to improve public health services to minimize the transmission rate of this outbreak. The second rule is to provide social assistance, especially to underprivileged people during this pandemic. The last is to increase the sector in the business world in relation to it as capital to deal with the ongoing pandemic.

\subsection{The Relationship of Economics and Sociology}

Smelser and Swedberg expressed their opinion regarding the definition of sociological and economic factors based on the views of Weber and Durkheim, in short, they argued that sociology and economics are a science that belongs to the sub-discipline category of sociology which has a disciplinary focus on the field of sociology where the object of discipline is about how people meet the needs of life.

From the description that has been described above, it can be concluded that the aspect of economic sociology is a field of study that has disciplines in various kinds of activities that have solid complexity including aspects of production, distribution, exchange and consumers of goods and services that are rare to be found in life public.

\section{METHODOLOGY}

\subsection{Identification}

Gender identification in tortoises was based on Iskandar [2] and Liat \& Das [4]. Identification of male and female gender is done by looking at the shape of the tail. In addition, how to identify gender can be distinguished by indicators on the shell, claws, and plastrons. Below is an example of gender identification of a tortoise:

\subsubsection{Shell}

Generally, the shells in male tortoise are longer and slimmer, while the shells in females are shorter and wider.

\subsubsection{Claws}

The claws of male tortoise are longer, sharper and flattened compared to females because the claws of males are usually used during the mating season with females. Apart from that, the claws are also used for defending territory as well as for fighting.

\subsubsection{Plastron}

In the case of the plastron, the male tortoise generally tends to be concave in shape. The shape of the plastron in such a way makes it easier for the male to adjust to the female's shell during the mating season. Meanwhile, plastron in females has a shape that tends to be flatter so that with such a shape the space in the female's stomach has more space to contain eggs.

\subsection{Morphological and Morphometric Characters}

The morphological characters that have been recorded relate to the shape of the head, the shape of the tail, the shape of the motion components (legs), the characteristics of the shield pieces on the carapace and plastron. The morphological characters recorded in this case refer to Kendrick \& Ades and Liat \& Das.

In other cases, the morphometric variables used to measure are the length of the curvature of the carapace and the width of the curvature of the carapace. The method regarding the form of this measurement variable adopts the indicator method derived from Kendrick \& Ades and Oktaviani.

The variability of the files in the structure of a particular part of the shape model of the tortoise shell can be manifested differently depending on the species. In some cases, anomalies have been recorded in the tail of the tortoise's carapace. Like the pattern on the plastron which is relatively more stable overall than the morphology. The shape and variation of the shell that is connected to the bone structure can be observed in: the shape and benchmarks on the unusual shape of the plat section are combined with the normal number of plats on the plat; the discovery of additional plats and there is no regular plat.

The flexibility that has been determined in the application of the theory of $\mathrm{H}$ with its relation in determining the number of variables, which will then be used as the sample of this study will have a visible impact on the wider space size and as an interpretation of the results of the data that has been carried out. In the process, a procedural methodology is carried out on a scientific engineering of the theoretical $\mathrm{H}$ model, which in the process of collecting data comes from objects that will be used as samples for the application of this theory as a whole $[9,10]$. The contents of this article can contribute to the assessment of public policies in controlling the level of spread that is actually occurring due to the Covid pandemic. The following are the points contained in this article: contains a brief and structured review of how historical and comparative a certain pandemic is, in this case the subject of discussion is the Covid pandemic and determine the form of the second 
model in order to carry out evaluation, especially on the ideal choice phenomenon in terms of the desired social aspects. In this case, it involves an exchange that occurs between boundaries in social life (taking into account the direct impact on the ongoing Covid pandemic) and measuring the level of activity in the economic sector.

\subsection{Data Analysis}

The analysis of the morphometric data that has been collected is applied using data from descriptive anatomy, which includes the number of tortoise carapace variations and standard patterns derived from theory $\mathrm{H}$ as well as interest in aspects of economic sociology in relation to the Covid pandemic. The data that has been described are then presented based on morphological characters using a qualitative descriptive method model. After the morphometric data and morphological characters have been collected, if the reference is based on morphogenetic characters, this anomaly is then subdivided into:

After the morphometric data and morphological characters have been collected, if the reference is based on morphogenetic characters, this anomaly is then subdivided into: the variation in evolution that occurs is due to changes in the number of axial elements of the skeleton in direct contact with the dermis (nerves and ribs); the variations that occur are due to changes in the number of scales of the peripheral skeleton; and variations related to osteogeny that work irregularly due to disturbances in impaired bone growth (suprapygal, leap plats, and fused plats) [11].

The evolutionary process in the tortoise carapace is generally formed through a series of modification processes that focus on the ribs and thoracic vertebrae, the ribs and thoracic vertebrae slowly undergo extensive ossification to form a solid bone structure [12].

In the application of scientific implementation in the field of Islamic studies must use a structured thinking pattern, as a study that studies Islam. In essence, it must underlie the processes that are reflected in the daily life of each individual, in accordance with the progress of contemporary Islamic scholarship [13].

This study uses data sourced from the Al-Quran and also the existence of real factors in the universe. The methodology in this study uses a systems approach based on the development of prophecy and its empirical values. The approach in this study uses descriptive analysis data, where this model approach has the comparative advantage of structured data [9].

The long-term negative effects that occur in the economic sector due to the Covid pandemic are generally measured using aggregate variables by collecting time series data gradually, this data usually includes various factors such as factors that affect production in the industrial world, factors contained in GDP growth, factors in the aspect of the unemployment rate, and others. The data that has been developed based on the weekly economic index (WEI) uses ten different economic variables from each data because this is intended to track the economic impact of Covid, especially in the US. Data collected in the period March 21 and March 28, if you refer to the results of the data from the study that WEI fell to $6,1 \%$. This is due to the declining level of consumer confidence, falling fuel sales, an increase in unemployment insurance claims (UI), and other related variables.

\section{ANALYSIS}

\subsection{Biology of Turtle, Dominant Species, and Morphological Description of Heosemys Spinosa}

Most tortoises have a shell that is covered with several parts, namely large epidermal scales, horned shields, and at the boundary there is a narrow hollow skin and horned grooves. In other squamate animals no scales were observed to form a mosaic. These scales have an elongated arrangement and have certain characteristics. In general, tortoises have scales with seven rows which are divided into two, namely five on the carapace and two on the plastron.

In general, the patterns on the tortoise shell and the parts of the horn scales are: (a) carapace, (b) plastron. Designations consist of: (C) central scute, (Im) inframarginal scute, $(\mathrm{M})$ marginal scute, $(\mathrm{P})$ pleural scute, (Pl) plastral scute, (Sm) supra marginal scute. Figures 1-12 show the serial number of scales, while the dotted lines show scales that are absent from most of the extant tortoises.

The scales in the center have an elongated pattern consisting of five horned elements and snap along the vertebral column. There is a row of pleura, each consisting of four large scales on each side. On the edges of the carapace, there are 12 pairs of smaller marrow scales. The ventral shell is lined by six paired plastral scales as well as side by side along the medial line. On the lateral part (the shell bridge), the third and fourth plastral scales are in direct contact with the marginal row. The scales from the tortoise shell do not form a distinct transverse line. This is due to a significant difference in size. Apart from tortoises, other reptiles such as lizards, snakes and crocodiles also have different scales. The pholidosis of the tortoise shell has two main characteristics which are almost incompatible with each other. On the one hand, the level of phylogenetic stability is high while on the other hand the individual variations are very diverse [14].

Paleontological data show that the tortoise shell pholidosis pattern that was formed in the early 
evolutionary phase has not undergone essential changes. This can be seen in the earliest tortoises, namely Proga Nochelys from the German Triassic [15] which exhibits the same pholidosis characteristics as the extant forms. The course of evolution shows that transformation involves only a few parts, such as the fea minor tures of horny mosaics; small inframarginal and supramarginal scales gradually disappear, the number of edges and plastic probes decrease slightly due to shortening of the direction of the trunk [16].

Dominant One of the dominant tortoise species is the brazilian tortoise species. This is because the brazilian tortoise is the most requested tortoise in Indonesia. The following is the morphological data of the brazilian tortoise biological classification: Animalia kingdom, Chordata phylum, Anapsida subclass, Testudines order, Emydidae family, Trachemys genus, Trachemys scripta and Trachemys scripta elegans subspecies.

Brazilian tortoises are native to the southern part of the United States. The lifespan of a Brazilian tortoise can reach around 25 to 30 years. Brazilian tortoise can grow to a maximum carapace length of $30 \mathrm{~cm}$.

Several studies have shown that the tortoise's way of life is reflected in its shell. The structure of the tortoise shell is very hard, and its shape is like a dome to protect it from predators. However, some tortoise species native to Africa have flexible and flat shell structures. This makes it easier for the tortoise to hide among the rocks.

The tortoise shell is a shield that has a very complex structure and serves to protect against predators or to protect it from shocks. The tortoise shell consists of two parts, namely the back (carapace) and the stomach (plastron). In this section there is bone tissue located between the front and hind limbs. Carapace is composed of cartilage found in dermal bones [17]

The carapace and plastron are connected by bony structures called bridges. Each part has two layers, namely the outer layer which has a structure of large and hard scales, while the inner layer has a structure in the form of tightly arranged plates. The tortoise shell consists of two parts, namely upper shell (Carapace) and lower shell (Plastron). Carapace is the top of the shell which has a round shape and has a fine texture. When a tortoise is a baby, the carapace structure is soft and bright green and has a stripe pattern of yellow and black. When the tortoise is an adult, the carapace will get harder and the green color will turn brown-black.

In general, carapace consists of 4 parts, namely Nuchal/cervical, the nuchal or cervical is a scute that is one in number and is small in size. This nuchal is found at the end of the shell just above the neck. Marginal, the marginal or peripheral is a series of small scutes located around the end of the carapace. The 2 marginal that are located at the bottom are called supracaudals. Pleural, Pleural or costal is a scutes that is in the form of 2 lines to flank the vertebrae. Vertebral, vertebral is a scutes that numbered five and is located in the middle.

Plastron is the lower shell which is softly textured and has a yellowish green color. Brazilian tortoises have a unique plastron pattern. The plastron in Brazilian tortoises can also indicate the sex. If the plastron is convex or flat, the sex is female. Meanwhile, if the plastron is concave, the sex is male. Plastron has 6 parts, namely, gular, humeral, pectoral, abdominal, femoral, anal. The lower side plastron has two parts, namely axillary and inguinal.

\subsection{The Structure of the Turtle Carapace and Plastron}

The thorn tortoise which has the Latin name Heosemys Spinosa is one of Indonesia's rare reptiles. The carapace at Heosemys Spinosa is oval in shape and has a brown to black color. This type of carapace has 5 vertebrae with keel, 1 nuchal chip, 4 costal pieces, and 12 marginal pieces. This type of carapace also has sharp serrations along the edges. This can be seen in figure (1a). In the plastron, the plastron cannot be moved (rigid) and the surface has a slippery structure. The gular, humeral, pectoral, abdominal, femoral, and anal parts have 2 pieces each. In the axillary, the disc is attached to the abdominal. This plastron has a radial pattern of black stripes. When compared to Cyclemys Dentata, the plastron pattern in this tortoise is thicker and has a different pattern. This can be seen in figure (1b).

Thorn tortoises have a black head and an orange color on the sides of the head and muzzle. The head of this tortoise species fits perfectly into the carapace. This can be seen in figure (1c). The webbed limbs and claws have black scales, there are also scattered orange scales in the form of spots that are clearly visible in the figure (1d). The tail of this thorn tortoise has a round and slender shape with black scales and orange spots, as can be seen in figure (1e).
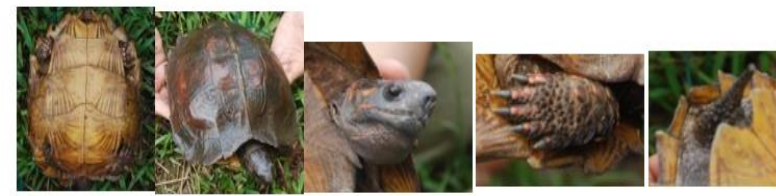

(a)

(b)

(c)

(d)

Figure 1. Morphology of Heosemys Spinosa which consists of carapace (a), plastron (b), head (c), legs (d), and tail (e). (Image Source: Research results) 
Table 1. Scute Patterns (Marginal And Prefrontal Scutes) Of Loggerhead Turtles In Different Mediterranean Areas.

\begin{tabular}{|l|l|l|l|l|l|l|l|l|l|l|l|l|}
\hline \multicolumn{2}{|c|}{ Area country Life Stage Marginal Scutes Other Prefrontal Scalase Source 12-13-4 $5+$} \\
\hline 1 & Central & Italy & Juveniles & 349 & 165 & 128 & 807 & 48 & 581 & 4 & 4 & Present Study \\
\hline 2 & Zakynthos & Greece & Adults & 32 & 9 & 1 & 28 & 6 & 54 & 9 & 1 & $\begin{array}{l}\text { Margaitioulis and Chiras } \\
(2011)\end{array}$ \\
\hline 3 & Belek & Turkey & Adults & 3 & 0 & 0 & 13 & 0 & & 5 & 6 & Turkozan et al (2001) \\
\hline 4 & Kizilot & Turkey & Hatchings & 61 & 47 & 33 & 303 & 30 & & 53 & 34 & Turkozan et al (2001) \\
\hline 5 & Fethiye & Turkey & Hatchings & 7 & 4 & 2 & 8 & 1 & & & & Turkozan et al (2001) \\
\hline 6 & Dalyan & Turkey & Hatchings & 3 & 0 & 5 & 18 & 0 & & & & Turkozan et al (2001) \\
\hline
\end{tabular}

Apart from the komodo, the valuable assets of ancient animals that are still alive on Komodo Island, East Nusa Tenggara, are the tortoise species in the Galapagos Islands. The Galapagos tortoise or the giant galapagos tortoise which has the Latin name Chelonoidis nigra is the largest living tortoise species and is a protected animal. The survival of these animals depends on the baby Galapagos tortoise bred in captivity.

Table 1 shows the scute patterns (marginal and prefrontal scales) of loggerhead tortoise in various regions of the Mediterranean. It can be seen that in several regions and countries each has a different pattern of skating, both on the marginal and prefront scales.

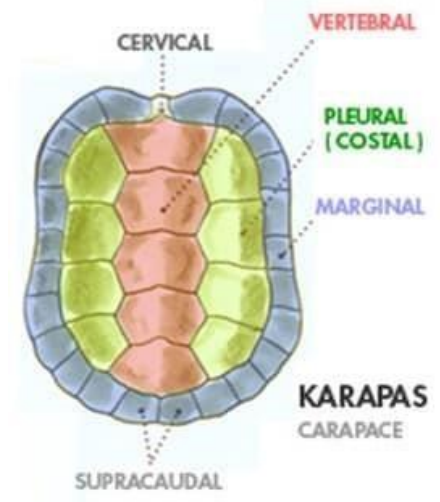

Figure 2. Structure of the Turtle Carapace

Figure 2 shows the number of vertebrae consisting of 3 scutes in the middle. Then the vertebral body is surrounded by a 10 scutes called pleural or costal. The marginal section consists of 24 scutes. The nuchal or cervical scute above consists of 1 scute.

Figure 3 shows the plastron structure consisting of gular, humeral, pectoral, abdominal, femoral, and anal which has a total of 2 scutes each. On the sides of the plastron are axillary and inguinal.

\subsection{Turtle with the Concept of Worship Using Theory $\mathrm{H}$}

In theory $\mathrm{H}$ contains the number 19 from the number 472319. Indirectly, the Al-Qur'an references the number 19 many times, as in the basmalah lafadz and in the initials of the surah. QS. Al-Hijr [15] verse 87, states that Allah has given the seven which is repeated and the whole of the Al-Qur'an. The meaning of "the repeated 7" is the number 7. Meanwhile, the meaning of "the Great Qur'an" holds the significance of the number 2319 which is obtained from the multiplication of 114 (Human and Through 2014). By using the theory of $\mathrm{H}$, the tortoise house and the Ka'bah are related to each other. This can be seen in QS. Ali'Imran [3] verse 96:

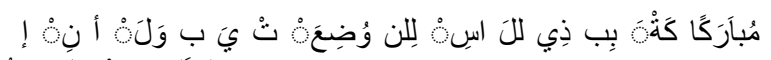

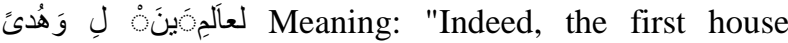
(worship) built for humans, is (Baitullah) which is in Bakkah (Mekkah) which is blessed and becomes a guide for all nature".

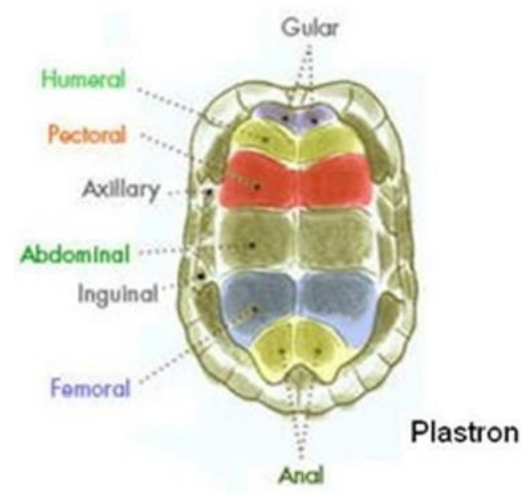

Figure 3. Structure of the Turtle Plastron

Bakkah in Arabic means pressure or pressure. The house built by Prophet Ibrahim was not the first house. This is because before Prophet Abraham, there was Prophet Adam. The first human was the early human Pithecantropus Erectus. The first houses were in the age 
of the dinosaurs. Along with dinosaurs, there are tortoises. So, the first house to be built by means of pressure was the tortoise house.

QS. Ali'Imran [3] verse 96 relates to the number of scutes on the tortoise's carapace which has the numbers $3,10,24$, and 1 . The number 3 represents the number of scutes in the vertebral column. Then the number 10 represents the number of scutes on the pleural or costal. The number 24 represents the number of scutes in the marginal portion. The number 1 represents the number of scutes in the nuchal. The numbers 24 and 1 add up to 24 $+1=25$. Then the number 25 is separated into unit numbers consisting of 2 and 5 . If added together, $2+5=$ 7. If using arithmetic, in QS. Ali'Imran [3] verse 96 has the numbers 3,9 , and 6 so the tortoise carapace has the numbers 3,10 , and 7 .

Apart from having a connection with QS. Ali'Imran [3] verse 96, the carapace and plastron of the tortoise reflect the numerals of Hahslm (472319). The number 4 is reflected in the plastron. The first 4 is found at the top of the plastron, which consists of 2 gular scutes and 2 humeral scutes. The second digit 4 is found in the center of the plastron, which consists of 2 pectoral scutes and 2 abdominal scutes. The third digit 4 is found at the bottom of the plastron which consists of 2 femoral and 2 anal scutes.

The number 72319 is reflected in the tortoise's carapace. The number 7 is reflected in the number of marginal scutes on the side. The number 2 is reflected in the large and small scutes. The number 3 is reflected in the number of nuchal scutes in the middle. The number 19 is reflected in the number of pleural or costal scutes that surround the nuchal scute as much as 10 , the number 10 is the sum of $1+9=10$.

From the explanation above, it can be concluded that the tortoise shell reflects the Islamic values described in Hahslm's theory (472319). This shows that everything created by Allah reflects the Islamic value in it.

\subsection{The Function of Turtle with Reference to Hahslm in the Era of Covid and Its Impact on Economic Sociology}

In addition to the tortoise shell, using theory $\mathrm{H}$, the number 19 is also found in the writing of Covid (Corona Virus Disease 2019), a virus that was first discovered in the city of Wuhan, China at the end of December 2019.

Covid has had a major impact on the economic sector, as it has affected business and financial markets globally. The lockdown policy implemented by the government caused supply chain delays [18].

Apart from the economic sector, Covid also affects other aspects, such as family, school, work routines, and feelings of insecurity and comfort. This pandemic also affects social factors, such as family support, social support, financial difficulties and social capital.

Several studies have shown the influence of social factors on mental health. The results of this study are that the individual who performs isolation is experiencing high anxiety and stress. This provides an awareness that psychological health must be of concern for individuals who isolate themselves during a pandemic.

During the Covid pandemic, more people with mental health problems compared to the number of people affected by the virus. Several previous studies have shown that infectious virus outbreaks, such as severe acute respiratory syndrome (SARS), can increase anxiety, stress levels, and depression in the general population [19].

When the Covid pandemic becomes more widespread in 2020, the President of the Republic of Indonesia, Joko Widodo, implements a new normal policy. But in reality, when the concession was implemented in June with the aim of encouraging economic recovery, this pandemic was not yet effectively controlled in Indonesia [20].

Several countries in the world have implemented policies to reduce the chain of spread of this epidemic, such as the imposition of lock downs. This policy has a profound impact on the economic sector and social system. Disruption of health has a direct impact on the social system and then on the economic sector. Selfisolation and social distancing have made drastic changes in everyday life, both physically and emotionally [21].

The United Nations (UN) believes that the Covid pandemic is not just a health crisis, but greatly affects the social and economic aspects of the country. This will increase the poverty rate globally.

After knowing that Covid has a profound impact on all aspects, the government and other parties must be responsive to efforts to minimize the impact of this pandemic. Without a quick response, the suffering from the pandemic will increase globally and endanger lives.

The UN, through its 131 country teams, is willing to serve 162 countries and territories to support national authorities in implementing public health preparedness and rapid response to the crisis caused by Covid.

In overcoming this crisis, the Indonesian government has issued a fiscal stimulus package through the National Economic Recovery (PEN) program. In 2020, the Government of Indonesia will allocate IDR 695,2 trillion (approximately US \$ 49 billion) for the program. In February 2021, the government reallocated a budget of Rp. 699,43 trillion (around US \$ 49,3 billion) for the continuation of the PEN program this year [22].

Indonesia continues to strengthen social protection programs to respond to the crisis caused by this pandemic. This is done to protect the middle to lower 
economic community. In addition, this program is also intended to protect small businesses. Several agencies such as UNICEF, UNDP, Prospera, and the SMERU Research Institute are collaborating on a groundbreaking survey at the end of 2020 to assess the impact of Covid on Indonesian households.

The survey in October and November 2020 was conducted involving 12,216 households representing 34 provinces. This survey is the largest Covid impact survey and focuses on children and vulnerable groups. This is based on interviews with households by the Central Bureau of Statistics Republic of Indonesia (BPS) as part of the 2019 National Socio-Economic Survey (SUSENAS). The impact of Covid will continue throughout 2021. In response to this, Indonesia's development partners provide support to improve the welfare of children and families.

The benefit of tortoise cultivation is to make tortoise species not go extinct. It can be concluded that the benefits of tortoise cultivation during the Covid pandemic are that it can help the economy of a community. In addition to the economic sector, tortoise cultivation can reduce anxiety and worry caused by the Covid pandemic.

\section{CONCLUSION}

The shape of the tortoise's unique carapace and plastron framework contains the concept of worship and is related to the Ka'bah. The results obtained based on this research are if the carapace of a tortoise which descriptively has a score of 3 and 1.9, is reflected in Islamic values in the Hahslm number 472319. Whereas if it refers to the marginal ones who have scutes totaling 24 and 1 nuchal in the numbers. If analyzed as a whole, you will get a result in the form of a number totaling 7 digits, which is reflected in the numbers $2+4+1=7$. In addition, other relationships that occur between the tortoise shell and the Ka'bah can be interpreted in the contents of the QS. Ali'Imran [3] verse 96. In addition to its relation to the tortoise carapace, Theory $\mathrm{H}$ can also be related to the Covid virus, this can be proven by referring to the number 19, where the number contained in the final sentence is based on the spelling word from Covid (Corona Virus Disease 2019). As is known, the current Covid virus has spread to various parts of the world. Many of the effects that arise are caused by this virus and tend to lead to negative impacts that affect many sectors in the economy, in addition to other impacts that are often encountered due to Covid leading to various aspects including socio-economic factors.

\section{REFERENCES}

[1] Iarhc, Aْne $\mathrm{B}$.,.Hंleina $\mathrm{D}$., renga $\mathrm{W}$. 2013. "Micro-Structure and Mechanical Properties of

the
eltruTंecaparaCं dleihS ${ }^{\circ}$ atcAंailairetamoiBं9(4):5890-5902.

[2] Adams, D.C., Rohlf, F.J., Slice, D.E. 2013: A field comes of age: geometric morphometrics in the $21 \mathrm{st}$ century. Hystrix 24: 7-14

[3] OtnayirdnA ,feirA adrivynnEं, itrainuY $\mathrm{Y}^{\circ} \mathrm{anA}, \mathrm{h}$ ayikaŻdna runiaakI ifoR 2021.ंehT"ंtcapmI $\therefore$ of Anxiety, Psychosomatic Disorders, Stress Trauma, and Socio-Economic Family Status on

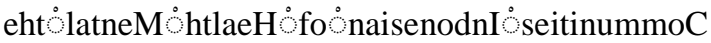
gnirud ".divoCं24(3):1-6.

[4] AmmeiruA ๖oznecniV ̊dna @araihC ¿.enoccannal 2020. ¿divoC" ‘ Pandemic: SocioEconomic secneuqesnoCंfólaicoSंgnicnatsiD serusaeMْं nï".ylati̊5(October): $1-8$.

[5] Aziz, R. M. 2020. Universe Created by Allah Equation of Hahslm 472319 as Big Bang

[6] Concept and Eid Pray Symbols. 408(Iconist 2019), 1-4. https://doi.org/10.2991/assehr.k.200220.001

[7] Aziz Aंnah kio Rं̊, damahco $\mathrm{M} \dot{\circ}$ dnåluru $\mathrm{N} \dot{\circ}$. hanasaH户.

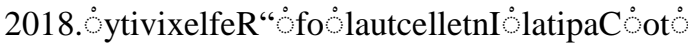
Assets in Jakarta 2018:121-36.

[8] AzizA ’nahkioR ’.damahcoM 2018

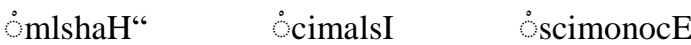
”.ygolodohteM $\dot{\mathrm{CESoCI}}$ (International Conference In Social, Economic and Culture)

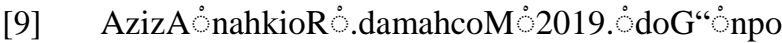

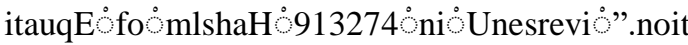
aerC Senatik 452-61.

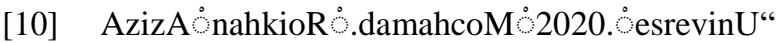

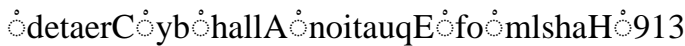
$274 \dot{\mathrm{s}} \mathrm{\circ}$

giB gnaBंtpecnoCंdnådiE’yarPْ”.slobmyS itsinocI $(804$ 2019):1-4.

[11] Bartik, Alexander, Marianne Bertrand, Zoe Cullen, Edward L. Glaeser, Michael Luca, and

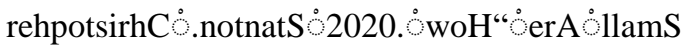
isessenisuB gnitsujdAंotं?divoC ylraEंecne $\operatorname{divE}$ morfंä".yevruSंNRSSं cinortcelËJ Journal.

[12] Bruner, E., Martin-Loeches, M., Colom, R. 2010: Human midsagittal brain shape variation: patterns, allometry and integration. Journal of Anatomy 216: 589-599.

[13] Cardini, A., Polly, D., Dawson, R., Milne, N. 2015: Why the long face? Kangaroos and

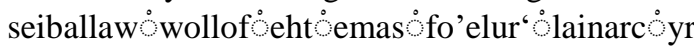


anoitulovéyrtemollå(AERC) $\dot{\text { sa }}$ pla- centals. Evolutionary Biology 42: 169-176.

[14] Casale, P., Mariani, P.

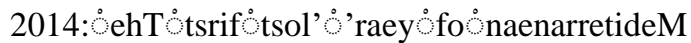

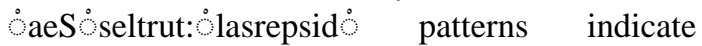
subregional management units for conservation. Mar. Ecol. Prog. Ser. 498: 263-274.

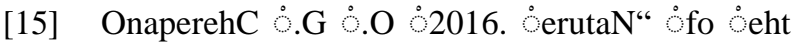
eltruT illehS: ‘citenegohproM ssesuaC fo @enoBं

Varytilibai@dnåstİyranoitulovE̊’.noitacilpmI ̊lacigolotnoelaP’̉anruoJ $50(14): 1641-48$.

[16] Cherepanov, G., Malashichev, Y., \& Danilov, I. 2019. yraremunrepuS tdependent model of the horny shell development in turtles. Journal of anatomy, 235(4), 836846.

[17] Chiari, Y., Hyseni, C., Fritts, T.H., Glaberman, S., Marquez, C., Gibbs, J.P., Claude, J., Caccone, A. 2009: Mor-phometrics parallel genetics in a newly discovered and endangered taxon of Galápagos tortoise. PLoS ONE 4: e6272.

[18] Dosik, M., \& Stayton, T. 2016. Size, shape, and stress in tortoise shell evolution. Herpetologica, 72(4), 309-317.

[19] Farke, C. M., \& Distler, C. 2015. Ontogeny and abnormalities of the tortoise carapace: A computer tomography and dissection study. Salamandra, 51(3), 231-244.

[20] ,ekraFoanitsirhC’.M̊dnåaidualC .reltsiD 20 15. ynegotnO" dnåseitilamronbA fóehtesi otroTं Carapace: A Computer Tomography

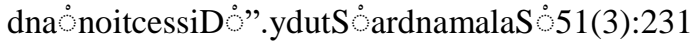
-44 .

[21] [20] Gonzalez, P.N., Kristensen, E., Morck, D.W., Boyd, S., Hallgrímsson, B. 2013: Effects of growth hormone on the ontogenetic allometry of craniofacial bones. Evolu- tion \& development 15: $133-145$.

[22] Han, B. S., Xu, Y. J., Guo, E. Y., Jing, T., Hou, H. L., \& Luo, L. S. 2018. Microstructure and Mechanical Properties of Tortoise Carapace Structure Bio-Inspired Hybrid Composite. Acta Metallurgica Sinica (English Letters), 31(9), 945952.

[23] Hirasawa, Tatsuya, Juan Pascual-Anaya, Naoki Kamezaki, Mari Taniguchi, Kanako Mine, and

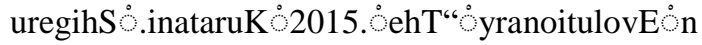

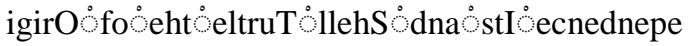
Dono eht laixA ثtserrA fo eht @inoyrbmE

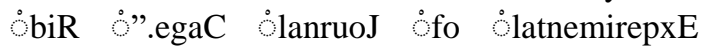

yggolooZ otraP $\dot{\mathrm{B}} \cdot \dot{\circ}$ Molecular and Developmental Evolution 324(3):194-207.

[24] Hui, D. S., I Azhar, E., Madani, T. A., Ntoumi, F., Kock, R., Dar, O., Ippolito, G., Mchugh, T. D., Memish, Z. A., Drosten, C., Zumla, A., \& Petersen, E. 2020. The continuing $2019 \mathrm{nCoV}$ epidemic threat of novel coronaviruses to global health - The latest 2019 novel coronavirus outbreak in Wuhan, China. International Journal of Infectious Diseases, 91, 264- 266. https://doi.org/10.1016/j.ijid.2020.01.009

[25] Hui, David S., Esam I Azhar, Tariq A. Madani, Francine Ntoumi, Richard Kock, Osman Dar,

[26] Giuseppe Ippolito, Timothy D. Mchugh, Ziad A. Memish, Christian Drosten, Alimuddin

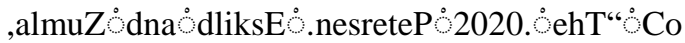
ntinuing 2019-NCoV Epidemic Threat of Novel

[27] Coronaviruses to Global Health - The Latest 2019 Novel Coronavirus Outbreak in Wuhan,

[28] "anihCஷ̊lanoitanretnİlanruoJ saesiD 91:264-66.

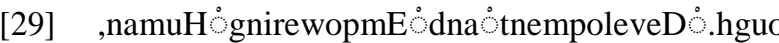
rhT 2014. neeteniN"ळsa doGं(1) and Worship )9(ْotowohS rorriM wodahS ni̊scitamehtaM

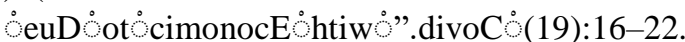

[30] Jongpairojcosit, N., \& Jearanaisilawong, P. 2017. Mechanical properties and numerical simulation of Sulcata tortoise carapace. Journal of the mechanical behavior of biomedical materials, 72 , 261-267.

[31] Jongpairojcosit, N., \& Jearanaisilawong, P. 2017. Mechanical properties and numerical simulation of Sulcata tortoise carapace. Journal of the Mechanical Behavior of Biomedical Materials, 72(February), 261-267. https://doi.org/10.1016/j.jmbbm.2017.04.012

[32] [28] Lawing, A.M., Polly, P.D. 2010: Geometric morphomet- rics: recent applications to the study of evolution and development. J. Zool. 280: 1-7.

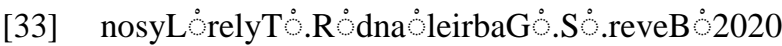
onigirO"dnånoitulovEீfo the eltruTंydoB'.nalP' Annual Review of Ecology, Evolution, and Systematics 51:143-66.

[34] Margaritoulis, D., Chiras, G. 2011: Scalation patterns of loggerhead turtles nesting in Lagans Bay, Zakynthos Island, Greece. Mar. Turtle Newsl. 131: 29-31.

[35] Marshall, C.D., Wang, J., Rocha-Olivares, A., Godinez- Reyes, C., Fisler, S., Narazaki, T., Sato, 
K., Sterba- Boatwright, B.D. 2014: Scaling of bite performance with head and carapace morphometrics in green turtles (Chelonia mydas). J. Exp. Mar. Biol. Ecol. 451: 91-97.

[36] Nicola, Maria, Alsafi, Catrin Sohrabi, Ahmed Kerwan, Ahmed Al-jabir, Christos Iosifidis, Maliha Agha, and Riaz Agha. 2020. The SocioEconomic Implications of the Coronavirus Pandemic (Covid): A Review. International Journal of Surgery 78(April):185-93.

[37] Oliver,G.2014:

’étilibairaVंtésnoitamroflamederulliacé'l’e dंalं, ennauoaCंatteraCं́atteracं (Linnaeus, 1758) (Reptilia Cheloniidae), sur les côtes françaises de Méditer- ranée. Bulletin Societe Herpetologie Francais 150: 9-23.

[38] Pasaribu, J., Ruyani, A., \& Suhartoyo, H. 2019. Studi perbandingan adaptasi Kura-Kura Pipi Putih (Siebenrockiella crassicollis) jantan dan betina di area Kolam Konservasi Universitas Bengkulu. PENDIPA Journal of Science Education, 3(1), 3339.

[39] Pragholapati, Andria. 2020. weN"'lamroN'aisenodnI 'retfÄdivoC’”.cim ednaP 2019:1-6.

[40] otowarPं,onaNंokEंoyirP ${ }^{\circ}$,omonruPंdnåahs

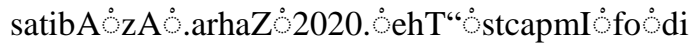
voCं

[41] Pandemic on SociocimonocÉ ytiliboMंnï".aisenodnİlanoitanret

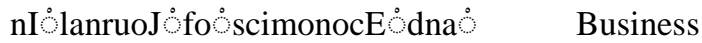
Administration 8(3):57-71.

[42] Qurniawan, T. F., Rusiana, D., \& Rachman, A. 2011. Analisis Variasi Bentuk Karapaks Kuya Batok (Cuora amboinensis Daudin, 1802) dan Bajuku (Orlitia borneensis Gray, 1873) dengan Metode Elliptic Fourier Descriptors. Majalah Ilmiah Biologi BIOSFERA: A Scientific Journal, 28(3), 152-158.

[43] Reiza, F., Kusuma, P. D., \& Prasasti, A. L. 2019. Pengembangan Motif Tempurung Kura-kura Jenis Terrapene Carolina Pada Aplikasi Berbasis Web. eProceedings of Engineering, 6(1).

[44] Repatterning, T. D. 2013. Origin of the Turtle Body Plan: The Folding Theory to Illustrate Turtle-Specific Developmental Repatterning. 3750. https://doi.org/10.1007/978-94-0074309-0

[45] Repatterning, Turtle-specific Developmental.

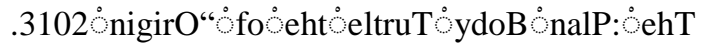
F Folding Theory to Illustrate Turtle-

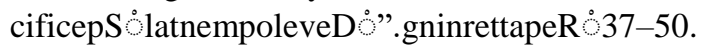

[46] Salmon, M., Scholl, J. 2014: Allometric growth in juvenile marine turtles: possible role as an antipredator adapta- tion. Zoology 117: 131-138.

[47] hcohcSंreniaRंRं2019.ं'Review Article The Origin Of The Turtle Body Plan: Evidence From Fossils And Embryos". 1-19.

[48] [43] Setiadi, A. E. (2012). Identifikasi Jenis Kura-Kura di Kalimantan Barat. In Proceeding Biology Education Conference: Biology, Science, Enviromental, and Learning (Vol. 11, No. 1, pp. 493-497).

[49] Smelser, Neil J. and Richard Swedberg. 2005. The Handbook Of Economic Sociology (Google EBook)

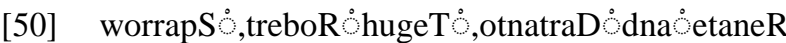

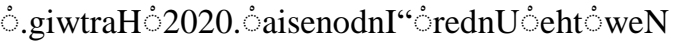

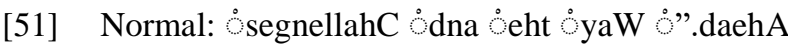
initelluB fo inaisenodnI icimonocE seidutSं 56(3):269-99.

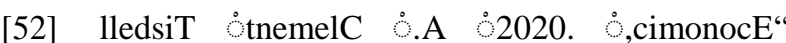

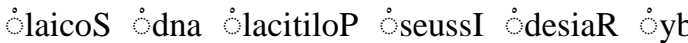
jeht divoC

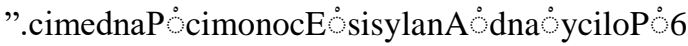
8:17-28.

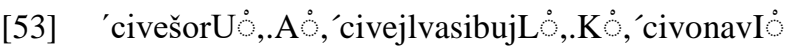
.Aं2014: Variation in skull size and shape of the common wall lizard (Podarcis muralis): allometric and non-allometric shape changes. Contributions to Zoology 83: 67-77.

[54] yelsmlaW jeirreT ,esiuoL madA ,esoR dna

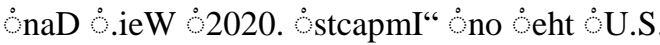

[55] ymonoceorcaM fo jyrotadnaM @ssenisuB

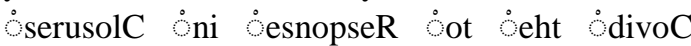
”.cimednaP' Applied Economics Letters 00(00):1-8.

[56] Yazdi, A.B. 2014: Application of geometric morphometrics to analyse allometry in two species of the genus Myrmica (Hymenoptera: Formicidae). 